\title{
Rockland County On-Line Index Book Software Unearths Eighteenth Century Land Records for Use by the Legal Community, Historians and the General Public
}

\author{
PETER J. SCHEIBNER, CA \\ Rockland County Archivist, 50 Sanatorium Road, Bldg. S, Pomona, NY 10980 USA \\ e-mail: scheibnp@co.rockland.ny.us
}

Rockland County On-Line Index Book Software Unearths Eighteenth Century Land Records for Use by the Legal Community, Historians and the General Public

\section{ABSTRACT}

The Rockland County Clerk offers on-line land records searches from the ease of your home computer 24/7. This is a major improvement over searching records through index books manually or having to sift through rolls of microfilm or hard copy deeds or mortgages. We are excited to report that thanks to grants received from the New York State Archive Local Government Records Management Improvement Fund, all Rockland County deeds and mortgages from 1798 to 1929 can now be searched and printed from your home computer by logging on to www.rocklandcountyclerk.com. Through innovative software known as On Line Books (OIB) developed by Cott Systems, Inc., Rockland County was able to save major time and resources on not having to dataenter all index books from 1798-1929 and then matching these indexes with the hundreds of thousands of actual deeds and mortgage pages. The software is both unique and innovative. You will find the details of using OIB in this issue.

Key words: land records, on-line search, use, The Rockland County

Il software dei registri online della Contea di Rockland porta alla luce documenti del XVIII secolo per l'utilizzo da parte della comunità legale, degli storici e del vasto pubblico

\section{SINTESI}

L'addetto alla Contea di Rockland offre online documenti della zona per la ricerca dal computer di casa. Questo è un grande miglioramento nella ricerca manuale dei documenti tramite registri o dovendo spostarsi fra rotoli di microfilm o copie cartacee e ipoteche. L'autore è lieto di riferire che grazie alle donazioni ricevute dal Fondo per lo sviluppo della gestione documentale delle amministrazioni locali dell'Archivio di Stato di New York, tutti gli atti di proprietà e le ipoteche della Contea di Rockland dal 1789 al 1929 possono ora venir cercati e stampati dal computer di casa iscrivendosi al sito www.rocklandcountyclerk.com. Tramite l'innovativo software chiamato On Line Books (OIB) sviluppato dalla Cott Systems, Inc., la Contea di Rockland ha potuto risparmiare tempo e risorse non dovendo inserire tutti i registri dal 1789 al 1929 e quindi gestire questi indici contenenti centinaia di migliaia di atti di proprietà ed ipoteche. Il software è unico ed innovativo. I dettagli di utilizzo dell'OIB sono presentati nell'articolo.

Parole chiave: documenti locali, ricerca on-line, utilizzo, contea di Rockland

Programska oprema On-Line Index Book okrožja Rockland omogoča uporabo zemljiške knjige osemnajstega stoletja pravnikom, zgodovinarjem in splošni javnosti

\section{IZVLEČEK}

Okrožje Rockland ponuja online iskanje po zemljiškoknjižnem gradivu preko domačega računalnika 24 ur na dan. To je velik napredek v primerjavi $z$ iskanjem zapisov s pomočjo indeksnih kartic, mikrofilma ali originalnega gradiva. $Z$ veseljem lahko sporočimo, da je na osnovi donacij, ki smo jih prejeli s strani posebnega sklada, mogoče dostopati do vseh zemljiško knjižnih listin in zastavnih pisem okrožja Rockland za čas od 1798 do 1929 iz domačega računalnika zgolj s prijavo na www.rocklandcountyclerk .com. Listine pa je možno tudi natisniti. $S$ pomočjo inovativne programske opreme, znane pod imenom On Line Books (OIB), ki jo je razvilo podjetje Cott Systems Inc., okrožje Rockland prihranilo veliko časa in sredstev, ki bi bili potrebni za vnos vseh indeksnih 
Peter J. SCHEIBNER: Rockland County On-Line Index Book Software Unearths Eighteenth Century Land Records for Use by the Legal Community, Historians and the General Public, 153-160

knjig za čas od 1798-1929 in mapiranje teh indeksov z dejanskimi dokumenti. Programska oprema je edinstvena in inovativna. Prispevek opisuje podrobnosti o uporabi OIB.

Ključne besede: zemljiškoknjižno gradivo, spletno iskanje, uporaba, okrožje Rockland

Rockland County was established in 1798 through an act of the New York State Legislature. Commonly known as "south of the mountains", prior to 1798, Rockland was part of Orange County which was formed in 1683 through a series of land patents. The English who settled in New York in 1664 maintained the land patent systems that were previously established by the Dutch. The area of what is now north Rockland was settled by the Dutch as far back as 1616 . This year marks the $400^{\text {th }}$ anniversary of Haverstraw. Tappan, an area in the southern part of what is now Rockland, is famous for being the site of one of many of George Washington's headquarters used during the Revolutionary War in America's battle for independence against the British. Tappan had its own courthouse prior to the formation of Rockland County.

The sale and acquisition of properties are legally conveyed through land deeds and have been filed by grantor and grantees (seller and buyer). Mortgages are loan documents between individuals or bank (lending institution or mortgagor) whereby a property buyer borrows money to purchase property (mortgagee). Each of the mortgages have a term of loan that must be adhered to. A ten or twentyyear loan with set terms regarding interest rates and payment terms was common. The Rockland County Archives stores and maintains the original deeds and mortgages in its records center/archive. The deed and mortgage collection consists of three distinct filing schemes that are important to understand. These filing sequences were established by past Rockland County Clerks who were responsible for the legal filing of such land papers. The first such filing and recordings for deeds and mortgages are from 1798-1907. The second such filing and recording is from 1908-1929. The third filing and recording is from 1930-current. The first two groupings of these records from 1798-1929 were only able to be searched and referenced manually through hardcopy books up until 2015 when we implemented the On-line-book search through software by Cott Systems, Inc. The recordings from 1930 through current years appeared only as on-line as indexes in the 1990's. From 2010-2015 deed and mortgage images were scanned and digitized and uploaded on-line on the County Clerk web-site.

It had been the plan of the Rockland County Clerk and County Archivist to bridge these recordings of deeds and mortgages into one on-line system so that they could all be searched, viewed and downloaded from an office or remote computer at all hours of the day or night. Our initial attempt was to database grantee and grantor indexes onto Microsoft Access so that we could search the indexes on-line. The index books were quite fragile and what had been microfilmed in the 1980's was often below resolution and density standards. We printed the indexes from microfilm and frequently had to go to the original books to verify names and spellings. We completed the 1798-1907 indexes by 2004 so that we could at least search deed names and reference the actual deed book and page. The deeds themselves were in deed books A-Z (1798-1854) and books 27- 232 (1854-1907). A deed which frequently had multiple names associated with them; for instance, the deed between Margaret Griffiths wife of John Griffiths and John M. Polhamus and his wife Elizabeth the sellers of a twenty-acre property to the First Reform Protestant Dutch Church in Clarkstown. These can be found through an OIB search by accessing grantor indexes for 1798-1907 by the grantor names. One can also access the grantee names for the same 1798-1907 period. The index provides the Book (78) and Page (512) dated $12 / 6 / 1872$. The deed is a four-page document that can be downloaded and printed. Most deeds from this period are at least two-page documents and can be ten or more pages depending on the size of the property and necessary legal details that need to be covered.

Title searchers and historians who search property records often have to go back as far as possible to search owners and buyers and prove meets and bounds of the real estate. In applying for National Registry designation on historic properties, a searcher has to trace the owners of a property back to its origins. On a 1760's property search this might entail going back through twenty previous owners with possible right-of-ways or foreclosures that might derail or detract the search at hand. In our English system of laws - deeds establish ownership of property and thus make these records a vital and permanent collection. 
Peter J. SCHEIBNER: Rockland County On-Line Index Book Software Unearths Eighteenth Century Land Records for Use by the Legal Community, Historians and the General Public, 153-160

We were able to database the 1908-1929 deed indexes by 2006 so that we could at least follow through with our goal to search deeds on-line. A search would still take upwards of fifteen to twenty minutes to find the deed on microfilm, scroll through the film and get a legible copy to print. The process was laborious and the quality of the deed image was always variable. $30 \%$ of the images were unreadable and would require that we go to the actual books which took even more time finding it on the proper shelf, pulling the book and hoping that the fragile pages do not get damaged any further.

\section{Rockland County deeds and mortgages 1798 -1929}

\section{The search just got easier pre-1930 deeds and mortgages go online}

Accessing all Rockland County deeds and mortgages is now as simple as sitting down at your computer and typing in www.rocklandcountyclerk.com. Within a few simple steps of entering this Web site, you can look up and access deeds and mortgages dated from 1798, when Rockland County was founded, to present day. Making these documents available to the public online has been a multiyear project, the final phase of which began in 2013 and ended in 2014 and covered the period from 1798 to 1929 . All told, nearly 434,000 deed, mortgage and index pages were digitized from hard copy books and up-loaded to the Rockland County Clerk Web site for this last phase of the project.

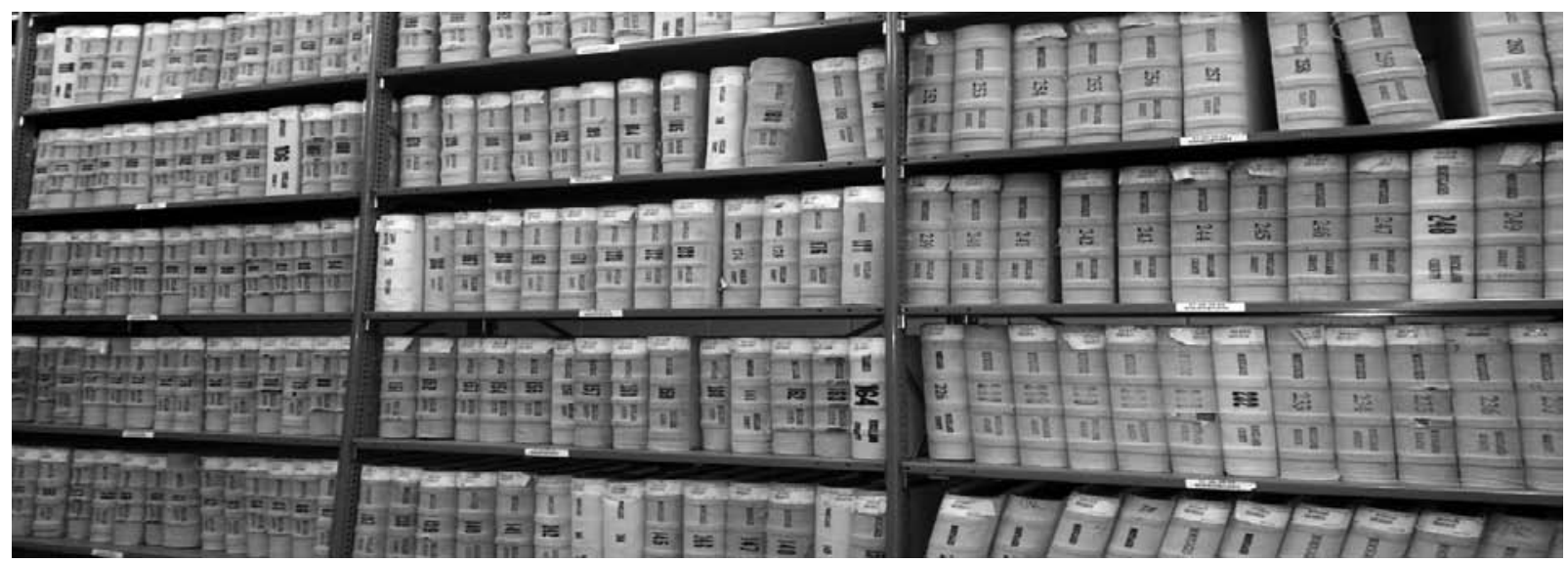

Image 1

Pictured above are some of the books from which the deeds and mortgages were scanned. In the final phase of this project, 187,850 mortgage images (representing 51,000 mortgages) and 221,950 deed images (representing 80,000 deeds) were scanned. A combined total of 14,000 mortgage and deed index images were also scanned. All told, approximately 433,800 images were scanned from 680 books.

\begin{tabular}{|c|c|c|}
\hline & Types of Images & Based On \\
\hline & 187,850 mortgage images & 51,000 mortgages \\
\hline & 221,950 deed images & 80,000 deeds \\
\hline Total & 409,800 images & $\begin{array}{c}131,000 \\
\text { deeds and mortgages }\end{array}$ \\
\hline
\end{tabular}


Peter J. SCHEIBNER: Rockland County On-Line Index Book Software Unearths Eighteenth Century Land Records for Use by the Legal Community, Historians and the General Public, 153-160

\section{Benefits}

Having the deeds and mortgages online benefits title searchers and members of the public because they don't need to travel to the County Clerk's office and wait for a staff member to find and print the requested document. And the County Clerk's office benefits because staff members spend much less time retrieving documents, allowing them to concentrate on other significant projects.

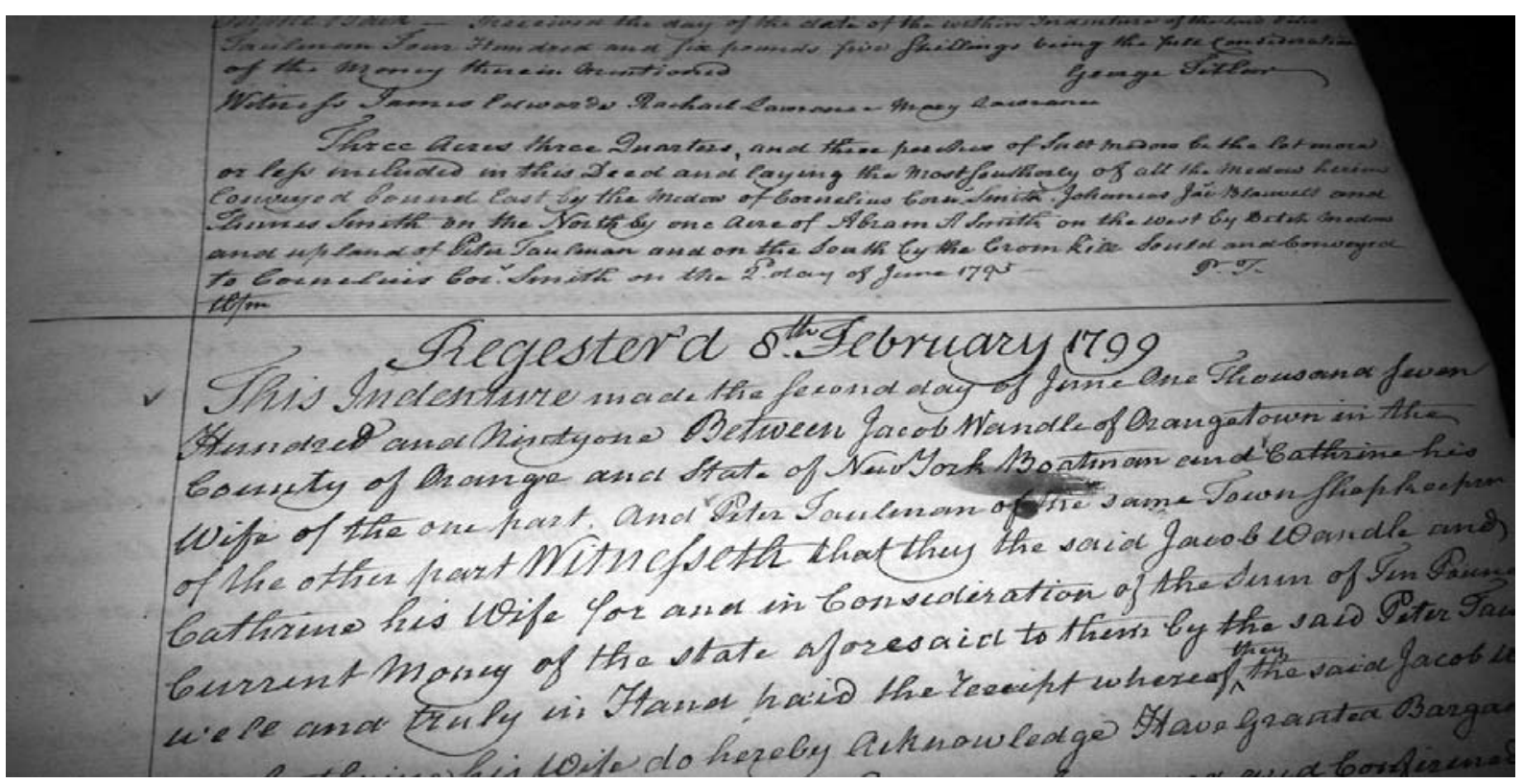

\section{Deed search}

\section{For the purposes of this paper and discussion we will concentrate on recorded deeds from 1798- 1929 rather than mortgages.}

We picked a name at random from one of the index books to use as an example of how to look up a deed. The individual selected, Irving E. Kimball of Tappan, NY, and his wife Edith, sold property to the New York Industrial Home and Bible School Association in 1907. To find the deed issued for this property:

- Type www.rocklandcountyclerk.com in the search bar of your Web browser (the site works with Internet Explorer, Mozilla Firefox or Google Chrome).

- Click on View Records on the top left-hand side of the Home page under the photo.

- Click on Sign in as a Guest on the top left-hand side under Account Sign-In. As a Guest, you can view and print documents at no charge. However, each page will appear and print with an „Unofficial“" watermark across it.

You must open an account to view and print documents without the water-mark. To do this, you need to create a user ID and a password of 5 to 18 characters. Other required information includes name, mailing address, phone number and e-mail address. Funds can be added to the account via a check or credit card (a 3 percent convenience charge is added); the printing fee (50 cents per page) is deducted from this amount. Pages of a document purchased through your account can be reprinted at no extra charge for up to 120 days.

- Click on Online Index Books on the second line of the page (Indexed Records). (From this tab you can search for deeds and mortgages from 1798 to 1929. To search for deeds and mortgages from 1930 to the present, follow the first three steps above and in the Name Search area enter the first and last name of the person associated with the document.) 

Records for Use by the Legal Community, Historians and the General Public, 153-160

- Select INDEX TO DEEDS 1798 thru 1907 from the Series Box drop-down menu and leave Grantor (the default) as the selection from the Party Box drop-down menu. Type Kimball, Irving $E$ in the blank box next to Firm/Last Name and click on Search. This brings you to the Index page that tells you where to find the deed. Thumbnails of each page of the threepage document appear on the left-hand side and are indicated as 1 of 3,2 of 3 and 3 of 3 . To move from page to page, you can 1) click on the thumbnail of the page you want to see, 2) go to the Toolbar and type in the page number in the box next to Jump to thumbnail and click on $G o$, or 3 ) click on the blue left and right arrow keys on the bottom of the page.

- Click on thumbnail 2 of 3 to see the entry for Edith and Irving E. Kimball. The entry is five lines up from the last listing. The surname (Kimball) is listed in the Grantor column, with Edith listed in the EFGH column and Irving E. listed in the IJ column. The Grantee column indicates that the property was sold to the „New York Ind. Home \& Bible School Assn.“. The Recorded column shows the month, day and year (March 12, 1907) that the deed was recorded and the book number (228) and page number (503) where the deed can be found. The Description of Property column shows that the Kimball's sold the Association three parcels of land consisting of 201 acres, 12.64 (12-64/100) acres and23 acres in Rockland and Bergen Counties.

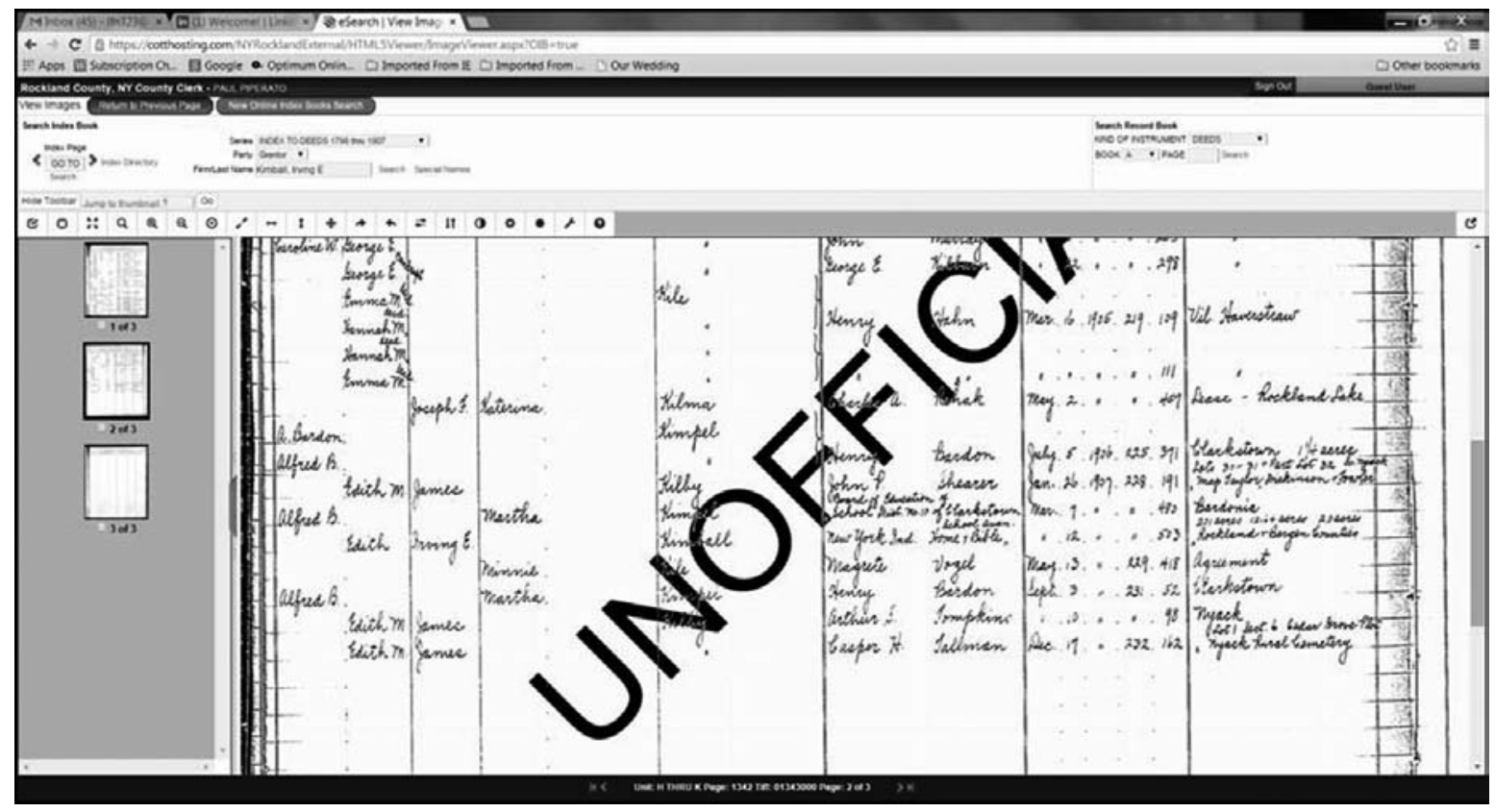

- Leave Deeds (the default) as the selection from the drop-down menu next to Kind of Instrument at the top right-hand side of the page. From the drop-down menu next to Book, select 228 (scroll through the alphabet to select numbers). Type 503 in the box next to Page, and click on Search.

This brings you to the deed, which starts on page 503 (in the page range of 481 to 622) and ends at the top of page 507.

\section{What Can You Do With Your Document?}

Now that you have found your document, there are a number of things that you can do with it. From the toolbar you can: 


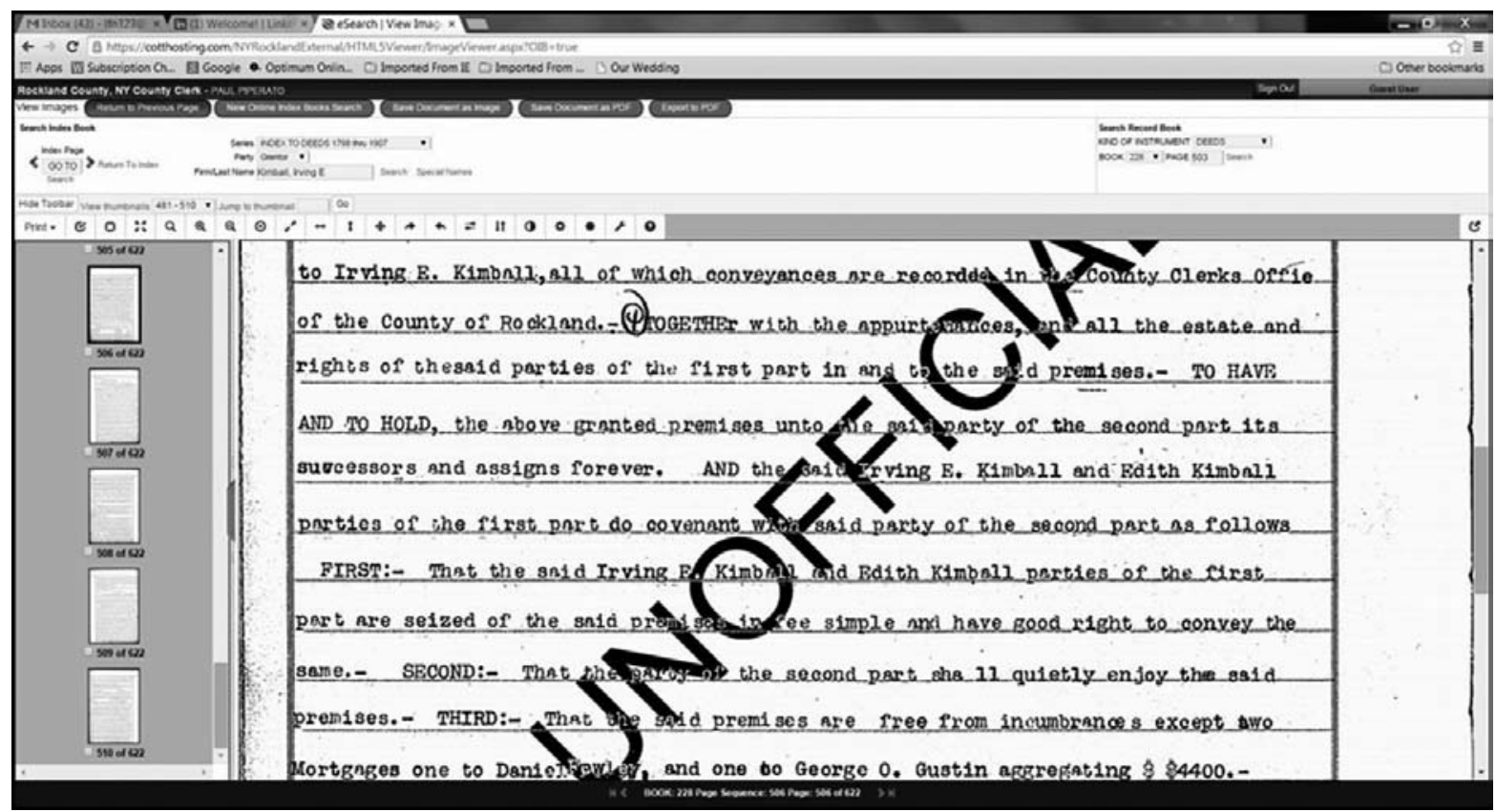

- Print: Click on the arrow next to Print to see four print options: 1) Print Current Page (prints the entire page currently on the screen); 2) Print Selected Pages(prints the pages selected by clicking on the box to the left of the page number under the thumbnail; pages don't need to be consecutive, for example, you can print pages 503, 506 and 507; 3) Visible (prints whatever is visible on the computer screen); and 4) Transformed (prints changes made to the image, such as inverting-i.e., changing the image from black on white to white on black).

- Select All Images: Automatically selects all the pages in the range, as indicated by the checkmark in the box before each page number.

- Clear All Selections: Clears all selected pages.

- Pan: Allows navigation up and down a page via an icon on the page image.

- Zoom: Changes the cursor to a cross used to designate an area to be enlarged.

- Zoom in: Enlarges the entire image.

- Zoom out: Decreases the entire image.

- Magnify: Magnifies a portion of the image by clicking on it and moving the mouse to the desired area.

- Actual size: Displays the image at the size it was scanned.

Users can also remove the thumbnail images from view by clicking on the dark blue spot on the side of the thumbnail panel and bring them back by clicking on the spot again. More information on what you can do with your document can be found by clicking on the question mark icon at the end of the tool bar and then General Image Viewing Functionality.

\section{Cost savings and efficiencies realized}

Through innovative software known as On Line Books (OIB) developed by Cott Systems, Inc. the Rockland County Clerk and Archives was able to save precious time and resources on having to digitally index over 131,000 deeds and mortgages from 1798 - 1929. Grantor and Grantee indexes for 80,000 deeds covering several distinct year ranges (1798 through 1907) and (1908 through 1908) while 51,000 Mortgagor and Mortgagee indexes for the same time period of years can also be searched. 
The beauty of the search is being able to view and print handwritten eighteenth century deeds and mortgages that were scanned at the highest resolution thus making them quite legible and readable. Prior to this point a researcher would have to view microfilm or fragile books and papers.

One of the major benefits that we have derived from this process is reduction of staff hours to retrieve deeds and mortgages. The information below shows staff time savings:

$\begin{array}{lll}\underline{\text { Series }} & \underline{\text { Time Saved(ea.) }} & \underline{\text { Total Saved }} \\ \text { Deeds (1798-1929) } & 9 \text { minutes } & 225 \text { Minutes } \\ \text { Mortgages (1798-1929) } & 12 \text { minutes } & 300 \text { Minutes }\end{array}$

*Total Savings Per Week:

525 Minutes or 8.75 Hours

*Total Savings Per Year:

455 Hours

*Based on 25 retrievals per week by staff

We reduced staff time retrievals by 455 hours. That is equal to 13 fulltime weeks (based on a 35-hour week). This reduction in time allows us to concentrate on other significant projects essential to records management. Rockland County realized a savings of over 455 hours of retrieval time, department/patron wait time was substantially reduced and 187,850 mortgage images and 221,950 deed images along with their respective indexes are now available on the internet at www.rocklandcountyclerk.com

\section{Realized benefits of OIB software:}

- Allows us to quickly print and certify required legal documents.

- Film searches are eliminated (the most time consuming step in retrieval).

- Allows us to add images to our internet website indexing system.

- Records accessed from the internet can be viewed and printed.

- Ability to retrieve images off of our computer and transmit as an email attachment.

- Hard copies searches are eliminated.

- Protection of original hardcopy documents.

\section{The contributions to the public from this project are outlined below:}

- Ability to search mortgagee/mortgagor indexes from 1798-1929 on the internet

- Internet access to 187,850 mortgage images from 1798 to 1929

- Internet access to over 51,000 individual mortgages taken from 289 Books from years 1798 to 1929

- Ability to search grantee/grantor indexes from 1798-1929 on the internet

- Internet access to 221,950 deed images from 1798 to 1929

- Internet access to over 80,000 individual deeds from 327 Books from 1798 to 1929

- Shorter waiting periods for records at both the County Clerk's Office and the Archives

- Increased staff time devoted to the public, resulting from not having to locate and retrieve documents manually.

Rockland County has developed and established a strong records management program that has been recognized by the New York State Archives, professional organizations, genealogists and the general public. It is with this dedication and commitment that we that we strive to improve our services to departments, researchers and the general public. As records management and technology evolves, we find ourselves in a better position to deliver fast and efficient access and retrieval to needed information. Imaging and document management will build upon existing databases and preservation microfilm that are already in place. Digital records, along with automated finding aids, will make records searching easy, useful and highly accessible. 
Peter J. SCHEIBNER: Rockland County On-Line Index Book Software Unearths Eighteenth Century Land Records for Use by the Legal Community, Historians and the General Public, 153-160

The On-Line Book software that we outline above allow searchers to scan on-line indexes and link them to actual images onto the Cott Systems servers used by the Rockland County Clerk Office. Public internet access allows searchers to view or download our earliest deeds and mortgages as a pdf or print image from their homes. The County Clerk website presently contains access to images of mortgages/deeds (1798 to present), discharge of mortgages (1804-1982), court records (2009-2016), subdivision and highway maps (1800 to present), as well as, incorporations and business certificates (1932-present).

\section{Used bibliography}

Much of the source material used in the paper comes from an "It's About Time" an archival newsletter published by the Rockland County Archives, Rockland County, New York Winter 2015 issue IX. "The Search Just Got Easier Pre-1930 Deeds and Mortgages Go Online" written by Lynn Nannariello.

Typology: 1.04 Professional Article

Submitting date: 14.01 .2016

Acceptance date: 20.02.2016 